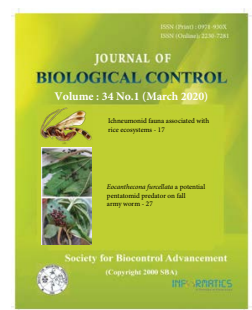

Research Article

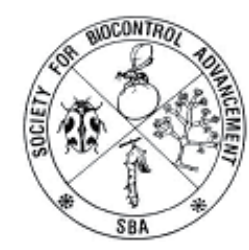

\title{
Antagonistic activity of cowshed Bacillus sp. bacteria against aflatoxigenic and sclerotic Aspergillus flavus
}

\author{
SHUBHRANSU NAYAK ${ }^{*}$, URMILA DHUA ${ }^{1}$ and SOMA SAMANTA ${ }^{2}$ \\ *Odisha Biodiversity Board, Regional Plant Resource Centre Campus, Nayapalli, Bhubaneswar-751015, Odisha, India \\ ${ }^{1}$ ICAR-National Rice Research Institute, Cuttack-753006, Odisha, India \\ ${ }^{2}$ Crop Protection Division, ICAR-National Rice Research Institute, Cuttack-753006, Odisha, India \\ *Corresponding author E-mail:shubhransu.crri@gmail.com
}

\begin{abstract}
Mycotoxins produced by many food spoilage fungi cause serious damage to human as well as to livestock. Aflatoxins are one such group of mycotoxins produced by Aspergillus flavus in many agricultural and food products including rice. The fungus can virtually grow in any environment and also produces resistive structures such as sclerotia to overcome unfavourable environmental conditions. Hence, the need of the time is to control this toxigenic and sclerotic fungus through an eco-friendly approach. In the current study four biocontrol bacteria belonging to Bacillus species were isolated from Indian cow shed environment and these bacteria could efficiently control not only the mycelia growth of A. flavus but also the germination and growth of sclerotia. Both active bacterial culture broth and cell free culture filtrate could limit the growth of the fungus up to more than $90 \%$. Older culture broth and filtrate lost their inhibition efficiency. Unlike many similar studies the current investigation emphasizes the importance of cowshed environment instead of cow dung and the control of sclerotia instead of fungal spores.
\end{abstract}

KEY WORDS: Aflatoxins, Aspergillus flavus, Bacillus, cowdung, mycotoxins, sclerotia

(Article chronicle: Received: 16-07-2019; Revised: 12-02-2020; Accepted: 25-02-2020

\section{INTRODUCTION}

Food spoilage is often associated with the infection of fungi which produce toxic secondary metabolites known as mycotoxins which are proven to have carcinogenic, teratogenic, mutagenic, immunotoxic, neurotoxic, nephrotoxic and hepatotoxic effects. The occurrence of mycotoxigenic moulds in foods constitutes a high risk for human and animal health (Blagojev et al., 2012). Aspergillus flavus is one of such mycotoxin producing fungi which infects and subsequently produces aflatoxins in cereal grains, oil seeds, fermented beverages made from grains, milk, cheese, meat, nut products, fruit juice and a wide range of other agricultural commodities (Zhang et al., 2008; Bennett and Klich, 2003; Li et al., 2011, Makun et al., 2007; Nayak et al., 2014). The fungus mainly produces aflatoxin $B 1$ and B2 where aflatoxin B1 is classified as Group 1A human carcinogen by the World Health Organisation-International Agency of Research on Cancer in 1993 (IARC, 1993), hence that is highly regulated in almost 77 countries (FAO, 2004).
This ubiquitous fungus can grow on any organic substrate (both living and dead plant tissues) and are superbly adapted to a wide range of environmental conditions which also produces resistant structures known as sclerotia. Sclerotia are pigmented, compacted aggregates of hyphae, which resist unfavorable environmental conditions and capable of remaining dormant for long periods which is often associated with aflatoxin production (Cotty, 1988; Wicklow and Shotwell, 1983; Rollins and Dickman, 1998).

To control and prevent the occurrence of A. flavus, it is necessary to replace chemical pesticides or fungicides to avoid environmental pollution, many health problems and destruction of non-targeted beneficial organisms. An important alternative is the use of antifungal properties produced by microbial Biological Control Agents (BCA) (Chitarra et al., 2003; Gheorghe et al., 2008). Bacillus species are good biological control agents (BCA) for their ability to produce different types of antimicrobial compounds, such as 
antibiotics e.g., bacilysin, iturin, mycosubtilin (Afsharmanesh et al., 2014; Mushtaq et al., 2010; Moyne et al., 2001). Among terrestrial bacterial strains, the genus of Bacillus has been well studied due to its ability to produce various types of inhibitory compounds (Stein, 2005). Both bacterial cell suspension and cell free culture filtrate have been found to be effective (Lim et al., 2008; Moshafi et al., 2011; Kong et al., 2010). The efficiency of Bacillus species to inhibit A. flavus and other post-harvest disease causing fungi has been discussed broadly in many reports (Kong et al., 2010; Pusey and Wilson, 1984). Several species such as Bacillus subtilis, B. amyloliquefaciens, B. vallismortis inhibited the growth of Aspergillus flavus (Das et al., 2013; Thakaew and Niamsup, 2013; Palumbo et al., 2007; Bhusan et al., 2013; Ranjbariyanet al., 2011). Cow dung served as a source for the presence of antifungal biocontrol agents and Bacillus species. Many Bacillus species isolated from cow dung have also been reported to possess antagonistic activity against many plant pathogens viz. Fusarium oxysporum, Botryodiplodia theobromae, Sclerotium rolfsii, Pythium aphanidermatum, Helminthosporium maydis and Rhizoctonia solani (Swain et al., 2008; Swain and Ray, 2009; Teo and Teoh, 2011). These bacteria are supposed to prevail in the indoor air of cowshed where cow-dung remains until it is cleaned by the residents. Hence cowshed environment also constitutes a source of antagonistic Bacillus bacteria.

Despite such importance, Bacillus bacteria present in cowshed environment have not been exploited for control of aflatoxigenic Aspergillus flavus. Hence, in the current investigation we have attempted to isolate bacteria belonging to Bacillus species from cowshed indoor air. Evaluation of these bacteria was carried out to observe their efficacy to inhibit mycelial growth and sclerotial germination under in vitro.

\section{MATERIALS AND METHODS}

\section{Bacteria strains}

Antagonistic bacteria were isolated by exposing Potato Dextrose Nutrient Agar media (PDNA) plates to cattle shed air for one minute and then incubating at $30^{\circ} \mathrm{C}$ for 24 hours. The bacteria colony appeared in the plate were then isolated and maintained as pure culture at Crop Protection Division of Central Rice Research Institute, India. Bacteria were identified by molecular method and the ITS sequences were submitted to NCBI GenBank. Four efficient bacteria designated as $\mathrm{BC} 1, \mathrm{BC} 2, \mathrm{BC} 5$ and $\mathrm{BC} 6$ (Table 1) belonging to Bacillus species were included in the current study for the evaluation of antagonistic activity.

\section{Aspergillus flavus isolates}

The two Aspergillus flavus isolates A2 and A28, used in the current study were obtained from Crop Protection Division of Central Rice Research Institute, India. A2 was aflatoxigenic strain where as A28 was aflatoxigenic as well sclerotia producing strain.

\section{Evaluation of antagonistic activity}

Bacterial isolates $\mathrm{BC} 1, \mathrm{BC} 2, \mathrm{BC} 5$ and $\mathrm{BC} 6$ were cultured in 50ml LB Broth for six hours and 24 hours in shaker at 250 $\mathrm{rpm}$ at $37^{\circ} \mathrm{C}$. This culture broth was mixed properly with luke warm PDNA@7ml/L of media. After the media solidified, fungal isolates (A28 and A2) were inoculated. Untreated control and four replicates of each treatment maintained throughout the experiment. The plates were incubated at $30^{\circ} \mathrm{C}$ and periodic growth in terms of colony diameter was recorded.

The inhibition percentage was determined as follows: $\frac{\text { Colony area of untreated control colony area of treatment }}{\text { Colony area of control }} \times 100$

Colony area $=\varpi r^{2}$

\section{Inhibition of sclerotia germination}

Sclerotia of isolate A28 were harvested by growing the fungus on PDA media and then collecting mature sclerotia with a sterilised brush. Sclerotia were then washed with sterilised water and dried properly before subjecting for experimentation.

To observe inhibition of sclerotia germination, $25 \mu \mathrm{l}$ of six hours and 24 hours culture broth of bacteria $(\mathrm{BC} 1$, BC2, BC5 and BC6) was put in separate cavity slides and then sclerotia were kept in it. For untreated control, sclerotia were kept in LB broth. Hundred sclerotia were taken for each treatment and control. The cavity slides were then incubated at ambient temperature inside humid chamber to prevent evaporation. The germination of sclerotia and formation of germ tubes were observed under $4 \mathrm{X}$ objective $15 \mathrm{X}$ eyepiece of an Inverted tissue culture microscope (Radical). Microscopic photography was done with a digital camera (Sony Cyber shot).

\section{Evaluation of germination or growth of sclerotia}

Germination and growth of individual sclerotia was observed and scored with 1 to 5 evaluation scale as: 1- Zero (no growth), 2- Poor, 3- Moderate, 4-Good and 5- Very good. Average mode was taken into consideration for the evaluation 
of sclerotia germination for each treatment and control.

\section{RESULTS AND DISCUSSION}

\section{Inhibition of mycelia growth}

Four bacteria belonging to Bacillus species were evaluated for antagonistic activity against aflatoxigenic and sclerotia producing isolates of Aspergillus flavus. The passport data of the bacteria is presented in Table $1 . \mathrm{BC} 1$ and $\mathrm{BC} 2$ were identified as Bacillus amyloliquefaciens where as BC5 and BC6 were B. vallismortis and B. subtilis, respectively. All the four bacteria efficiently inhibited the mycelia growth of both the fungi though a definite inhibition pattern was lacking. Periodic growth of A. flavus strains A2 and A28 were significantly reduced by the four bacteria (Table 2 and Fig. 1). A2 was more susceptible. The colony diameter (cd) of untreated $\mathrm{A} 2$ was $37.3 \mathrm{~mm}$ on third day of growth whereas that of $\mathrm{A} 2$ treated with $\mathrm{BC} 1, \mathrm{BC} 2, \mathrm{BC} 5$ and $\mathrm{BC} 6$ were $12.6 \mathrm{~mm}$, $12 \mathrm{~mm}, 10.3 \mathrm{~mm}$ and $11.6 \mathrm{~mm}$ respectively. Similarly, the cd of untreated A28 on third day was $40.3 \mathrm{~mm}$ whereas that of A28 treated with $\mathrm{BC} 1, \mathrm{BC} 2, \mathrm{BC} 5$ and $\mathrm{BC} 6$ were $15.3 \mathrm{~mm}$, $14.6 \mathrm{~mm}, 14.3 \mathrm{~mm}$ and $15.6 \mathrm{~mm}$ respectively. Higher inhibition was exhibited by B. vallismortis (BC5). In terms of area of mycelia colony, BC5 showed $92.3 \%$ inhibition towards A2 followed by B. subtilis (BC6) which showed $90 \%$ inhibition (Fig. 2). BC1 and BC2 (B. amyloliquefaciens) showed 88.6\% and $89.3 \%$ inhibition to $\mathrm{A} 2$ respectively. Higher reduction in colony area of A28 was shown by BC5 with $87.3 \%$ inhibition followed by BC2 which showed $86.7 \%$ inhibition. BC1 and BC6 exhibited $85.7 \%$ and $85 \%$ inhibition.

Table 1. Passport data of Bacillus bacteria isolated from cowshed atmosphere

\begin{tabular}{|c|c|c|}
\hline *Isolate ID & $\begin{array}{c}\text { NCBI GenBank } \\
\text { Accession no. }\end{array}$ & Identified Organism \\
\hline BC1 & JF304104 & Bacillus amyloliquefaciens \\
\hline BC2 & JF304105 & Bacillus amyloliquefaciens \\
\hline BC5 & JQ753710 & Bacillus vallismortis \\
\hline BC6 & JF304107 & Bacillus subtilis \\
\hline
\end{tabular}

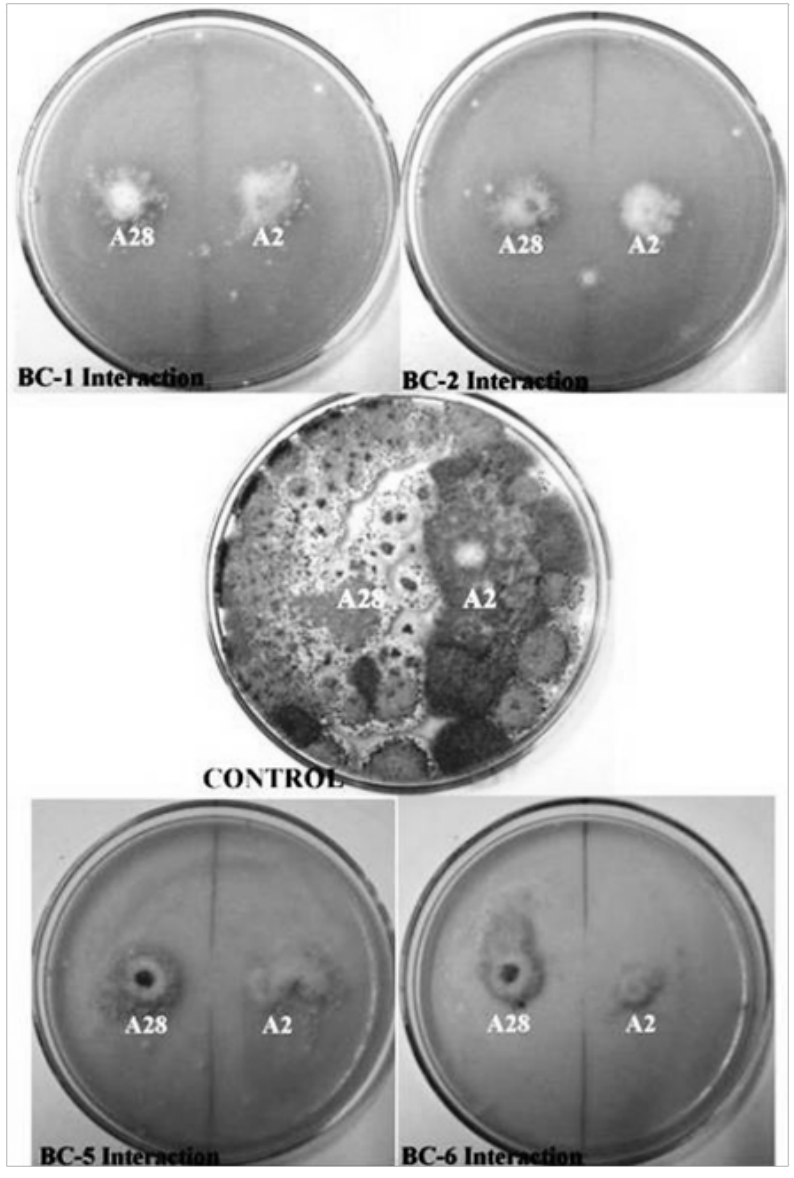

Fig. 1. Inhibition of Aspergillus flavus (A2 and A28) by culture broth of antagonistic bacteria isolated from cowshed environment

Efficiency of bacterial culture broth and culture filtrate to inhibit sclerotia germination and growth was evaluated (Table 3; Fig. 3 and 4). Formation of germ tubes were scored in a 1 to 5 scale range and average mode was taken into consideration for each treatment and control. In control, where sclerotia were kept in LB broth, very good growth (5-average mode) was observed. Contrary to this no growth (100\% inhibition) was observed in more than $90 \%$ cases where sclerotia were kept in six hours culture broth of all bacteria. In these cases only $5 \%$ showed poor germination. The cell free culture

Table 2. Effects of culture broth of cowshed bacteria on colony diameter of aflatoxigenic Aspergillus flavus isolate A2 and $\mathbf{A} 28$

\begin{tabular}{|c|c|c|c|c|c|c|}
\hline \multirow{3}{*}{ Bacteria ID } & \multicolumn{6}{|c|}{ Periodic observation on Colony diameter(mm) of A. flavus isolates } \\
\hline & \multicolumn{3}{|l|}{$\mathrm{A} 2$} & \multicolumn{3}{|l|}{ A28 } \\
\hline & Day I & Day II & Day III & Day I & Day II & Day III \\
\hline $\mathrm{BC} 1$ & $4.3 \pm 0.3$ & $5.3 \pm 0.3$ & $12.6 \pm 0.0$ & $5.0 \pm 0.0$ & $10.6 \pm 0.7$ & $15.3 \pm 0.3$ \\
\hline $\mathrm{BC} 2$ & $4.3 \pm 0.3$ & $6.3 \pm 0.3$ & $12 \pm 0.0$ & $4.6 \pm 0.3$ & $10.0 \pm 0.6$ & $14.6 \pm 0.9$ \\
\hline $\mathrm{BC} 5$ & $4.3 \pm 0.3$ & $6.3 \pm 0.7$ & $10.3 \pm 0.3$ & $5.3 \pm 0.3$ & $9.0 \pm 0.6$ & $14.3 \pm 0.3$ \\
\hline BC6 & $5.6 \pm 0.3$ & $6.6 \pm 0.3$ & $11.6 \pm 0.3$ & $7.3 \pm 0.7$ & $10.3 \pm 0.7$ & $15.6 \pm 0.3$ \\
\hline Untreated Control & $19 \pm 0.6$ & $28.3 \pm 0.3$ & $37.3 \pm 0.3$ & $25.6 \pm 0.3$ & $35.0 \pm 0.0$ & $40.3 \pm 0.3$ \\
\hline
\end{tabular}

LSD at $\mathrm{p}<0.05$ is 1.05

LSD at $\mathrm{p}<0.01$ is 1.42
LSD at $\mathrm{p}<0.05$ is 1.39

LSD at $p<0.01$ is 1.89 


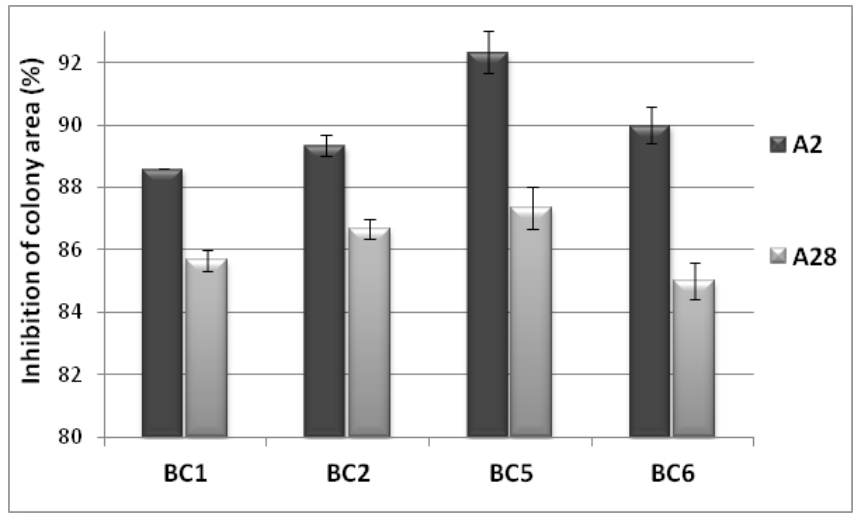

Fig. 2. Inhibition of colony area of aflatoxigenic Aspergillus flavus A2 and A28 by Bacillus species. Inhibition of sclerotia germination and growth

filtrate (ccf) of all bacteria was also able to minimise the sclerotia germination where moderate germination/growth (3-average mode) was observed. However, in case of $\mathrm{BC} 1$ and BC6 the scale range went up to 4 i.e. good growth in some observations. In comparison to bacterial culture broth grown for six hours which completely inhibited sclerotia growth, poor germination/growth (2-average mode) was observed in sclerotia kept in 24 hours old culture broth. The range of growth scale also ranged from 2 (poor growth) and increased to 3 i.e., moderate growth. Contrary to bacterial cell suspension the ccf of 24-hour old culture showed lower inhibition where moderate growth was observed (3-average mode). The ccf (24hours) of B. vallismortis (BC5) showed relatively better inhibition as the maximum growth scale was 3 whereas the ccf for other bacteria tested was increased up to 4 (Table 3). From the above observations it is clear that six hours old bacterial culture broth was the most effective to control sclerotia germination/growth than 24 hours old.

Antagonism is the relation between two species of opposite organisms, in which one affects the life of the other, inhibiting partially or totally its growth or even killing it. The mechanisms of antagonism observed in nature are competition, antibiosis, predation and hyperparasitism. Antibiosis is the inhibitory effect of one microorganism against the physiological processes of another (Luna-Romero et al., 2007). Bacteria belonging to Bacillus sp. are considered to be good agents of antibiosis and their efficiency to inhibit many crop pathogens including aflatoxigenic $A$. flavus have been well documented. Crude extract of $B$. amyloliquefaciens could inhibit $A$. flavus with more than $10 \mathrm{~mm}$ inhibition zone (Das et al., 2013). An antagonist B. subtilis BCC 6327 was shown to inhibit the growth and spore germination of aflatoxigenic fungus. The cell free supernatant from 12, 24 and $36 \mathrm{~h}$ of incubation could inhibit the growth and mycelium production with inhibition percentages of 92.1, 89.6 and 90.1\%, respectively (Thakaew and Niamsup, 2013). Hai

Table 3. Effect of antagonistic cowshed bacteria on germination and growth of Aspergillus flavus sclerotia

\begin{tabular}{|c|c|c|c|c|c|}
\hline S1. No. & Test material & $\begin{array}{l}\text { Treatments } \\
\text { (antagonistic bacte- } \\
\text { ria/control) }\end{array}$ & $\begin{array}{l}\text { *In 1-5 scale evalua- } \\
\text { tion of germination / } \\
\text { growth of sclerotia } \\
\text { (average- mode) }\end{array}$ & $\begin{array}{c}* \text { In } 1-5 \\
\text { scale range }\end{array}$ & Remarks \\
\hline 1. & \multirow{4}{*}{$\begin{array}{l}\text { Culture Broth } \\
\text { (6 hrs old) }\end{array}$} & $\mathrm{BC} 1$ & 1 & $1-2$ & \multirow{4}{*}{$\begin{array}{l}\text { Sclerotia did not germinate in } \geq 90 \% \text { cases but in } \\
\text { about } 5 \% \text { sclerotia poor germination observed }\end{array}$} \\
\hline 2. & & $\mathrm{BC} 2$ & 1 & $1-2$ & \\
\hline 3. & & $\mathrm{BC} 5$ & 1 & $1-2$ & \\
\hline 4. & & BC6 & 1 & $1-2$ & \\
\hline 5. & \multirow{4}{*}{$\begin{array}{l}\text { Culturefiltrate } \\
\text { of ( } 6 \text { hrs old })\end{array}$} & $\mathrm{BC} 1$ & 3 & $1-4$ & Moderate growth \\
\hline 6. & & $\mathrm{BC} 2$ & 3 & 3 & Moderate growth \\
\hline 7. & & $\mathrm{BC} 5$ & 3 & 3 & Moderate growth \\
\hline 8. & & BC6 & 3 & $2-4$ & Moderate growth \\
\hline 9. & \multirow{4}{*}{$\begin{array}{l}\text { Culture Broth } \\
(24 \text { hrs old })\end{array}$} & $\mathrm{BC} 1$ & 2 & $2-3$ & In $\leq 90 \%$ poor germination \\
\hline 10. & & $\mathrm{BC} 2$ & 2 & $2-3$ & In $\leq 90 \%$ poor germination \\
\hline 11. & & $\mathrm{BC} 5$ & 2 & $2-3$ & In $\leq 90 \%$ poor germination \\
\hline 12. & & BC6 & 2 & $2-3$ & In $\leq 90 \%$ poor germination \\
\hline 13. & \multirow{4}{*}{$\begin{array}{l}\text { Culturefiltrate } \\
\text { of ( } 24 \mathrm{hrs} \\
\text { old })\end{array}$} & $\mathrm{BC} 1$ & 3 & $2-4$ & In $\leq 80 \%$ moderate growth \\
\hline 14. & & $\mathrm{BC} 2$ & 3 & $2-4$ & In $\leq 80 \%$ moderate growth \\
\hline 15. & & $\mathrm{BC} 5$ & 3 & 3 & Moderate growth \\
\hline 16. & & BC6 & 3 & $3-4$ & In $\leq 70 \%$ moderate growth \\
\hline 17. & LB Broth & Control & 5 & 5 & Very good germination and growth \\
\hline
\end{tabular}




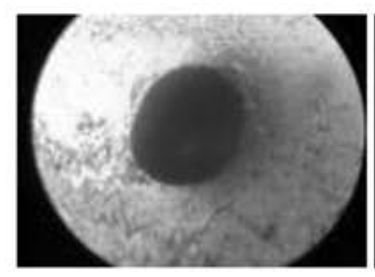

1-No growth

2-Poor
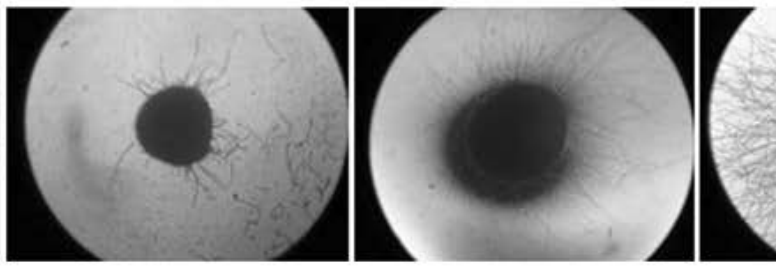

3-Moderate

-Good
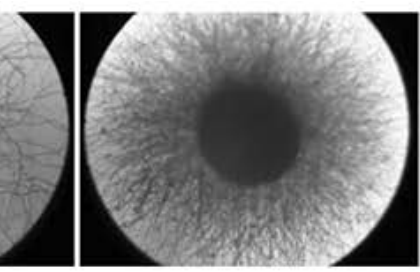

5 -Very good

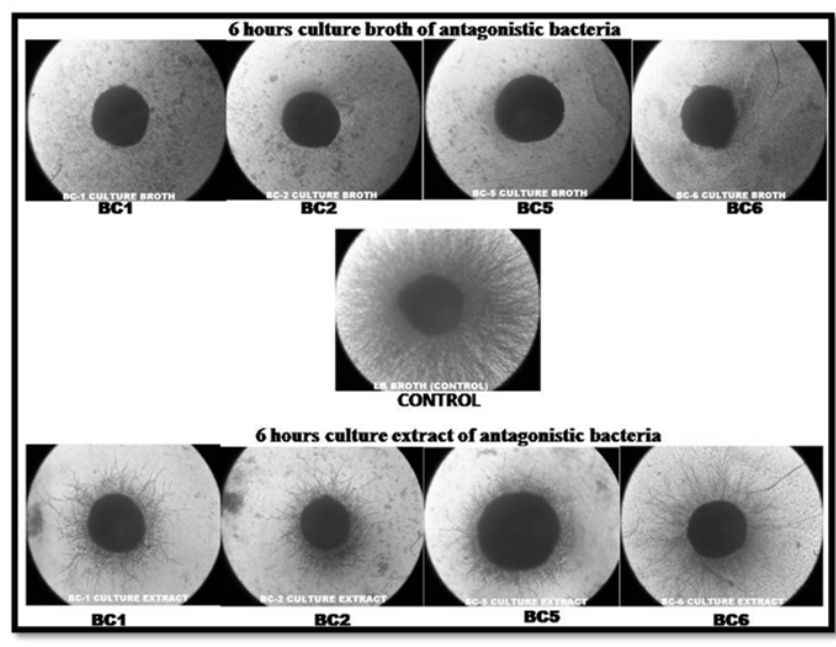

Fig. 3. Inhibition of sclerotia germination of Aspergillus flavus A28 by six hours culture broth of antagonistic bacteria

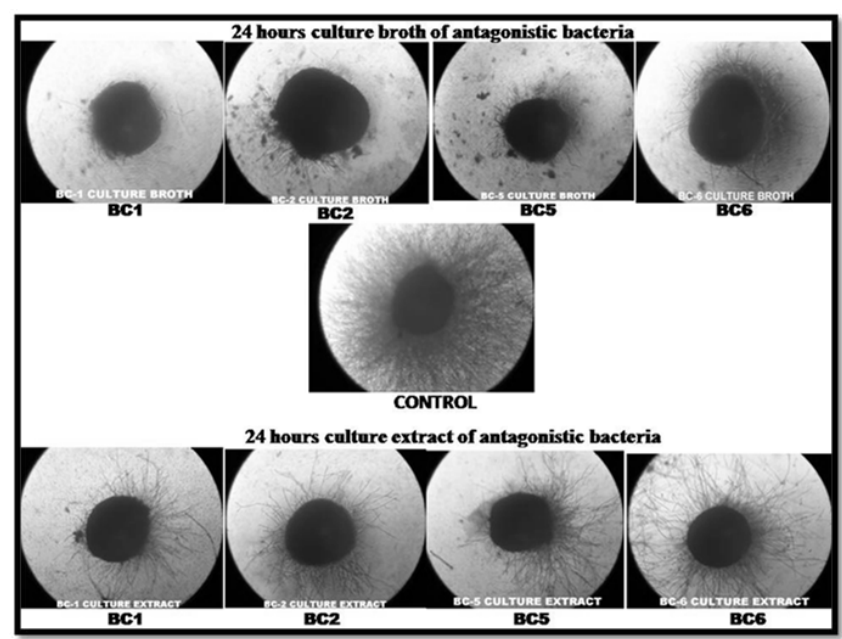

Fig. 4. Inhibition of sclerotia germination of Aspergillus flavus A28 by twenty four hours culture broth of Bacillus species

(2006) reported that B. subtilis metabolites inhibited both spore germination and hypha elongation, causing the decrease of fungal development. Bacillus subtilis also exhibited more antagonistic effect than Pseudomonas to seed-borne mycoflora A. flavus (Bhushan et al., 2013). Palumbo et al. (2007) selected Bacillus strains for the quantitative antifungal assays which significantly inhibited A. flavus in different media. Ranjbariyan et al. (2011) tested strains of B. subtilis, B. amyloliquefaciens and B. vallismortis and observed $49 \%$, $60.1 \%$ and $60 \%$ inhibition, respectively to A. flavus.

Lim et al. (2008) found bacterial culture broth and Cell-free Cultural Filtrate (CCF) to be both effective and ineffective against mycelia and undiluted culture broth was more useful. Bacterial cell suspension effectively inhibited aflatoxin biosynthesis as reported by Kong et al. (2010). He observed that when the incubation time of B. megaterium was $60-\mathrm{h}$, the rate of decay declined to $41.67 \%+/-2.89 \%$. In a study by Moshafi et al. (2011) CCF of soil Bacillus sp. inhibited Aspergillus. In present study, the four Bacteria of Bacillus species viz. B. amyloliquefaciens (BC1), B. amyloliquefaciens (BC2), B. vallismortis (BC5) and $B$. subtilis (BC6) which were isolated from cowshed indoor air, were found to be effective in controlling the mycelial growth or hyphal elongation as well as sclerotia germination or growth under in vitro. In earlier reports Bacillus sp. bacteria isolated from cow dung could control crop pathogens. Bacillus cereus and Bacillus subtilis isolated from cow dung could reduce the growth of Sclerotium rolfsii, Fusarium oxysporum, Pythium aphanidermatum, Helminthosporium maydis and Rhizoctonia solani with inhibitory zones of up to $58 \%$ (Teo and Teoh, 2011). The B. subtilis strains from cowdung inhibited the growth of fungi in vitro, F. oxysporum (25-34\%) and Botryodiplodia theobromae (100\%) (Swain et al., 2008; Swain and Ray, 2009).

Cow dung micro flora contains abundant number of Bacilli. There are several evidences to show that fresh cow dung and cow urine are antifungal and antiseptic in nature which might be due to secretion of antimicrobial metabolites by cow dung micro flora (Sharma and Singh, 2015). Hence the indoor air of cowshed may constitute a sphere of antagonistic bacteria. Cow dung is traditionally used as organic fertilizer in Indian sub-continental farming for centuries. People in Indian villages regularly coat their huts with cow dung slurry and usually cowshed remains at close proximity to their living area. It is a general observation that those people rarely face any fungal allergic reactions like sick building syndrome. The presence of these antagonistic 
bacteria may be involved in suppression of the fungi. However this needs more comprehensive study.No research has been carried out on Bacillus species from cowshed environment to evaluate antagonistic activity against aflatoxigenic and sclerotia producing A. flavus. Sclerotia form an important structure of $A$. flavus aiding in its survival under unfavourable conditions as well as aflatoxin production. Sclerotia present in infected food materials and agricultural commodities may cross geographical boundaries during transportation and thereby may spread infection as well as aflatoxin contamination. However, no report was found regarding the inhibition of sclerotial germination or growth of this important aflatoxigenic fungus. In the current study, active cell suspension (six hours old culture broth) of all Bacillus bacteria completely inhibited the sclerotia germination. Bacterial ccf and older cell suspension ( 24 hours culture broth) was also found to be effective in inhibiting germ tube formation though the efficiency was lower than that of active cell suspension. These bacteria might have inhibited fungi by producing antifungal enzymes and proteins which might degrade fungal cell wall or toxins which interfered with fungal metabolism. Those compounds might be heat labile or stable. Further study may confirm about the physical and chemical property of antifungal compounds produced by these useful bacteria.

\section{CONCLUSION}

Presence of aflatoxins in many agricultural products is a serious concern. The causal organism Aspergillus flavus produce sclerotia to perpetuate during unfavorable conditions. Cowshed bacteria belonging to Bacillus species were found to be very effective against aflatoxigenic and sclerotic isolates of A. flavus. Fresh bacterial cultures were more efficient to control the germination and growth of sclerotia.

\section{ACKNOWLEDGEMENTS}

Authors are grateful to the Director, ICAR-National Rice Research Institute, India for providing necessary facilities. Authors are also thankful to the Chairman and Member Secretary, Odisha Biodiversity Board, Bhubaneswar, India.

\section{REFERENCES}

Afsharmanesh H, Ahmadzadeh M, Javan-Nikkhah M, Behboudi K. 2014. Improvement in biocontrol activity of Bacillus subtilis UTB1 against Aspergillus flavus using gamma-irradiation. Crop Prot. 60: 83-92.https:// doi.org/10.1016/j.cropro.2014.02.013.

Bennett JW, Klich M. 2003. Mycotoxins. Clinic Microbiol Rev. 16(3): 497-516.DOI: $\quad 10.1128 / \mathrm{cmr} .16 .3 .497-$ 516.2003
Bhushan G, Chhangani S, Singh J and Singh AP. 2013. Antagonistic effects of Bacillus subtilis and Pseudomonas fluorescens against seed-borne $\mathrm{M}$ ycoflora of Pennisetum americanum. J Env Sci Technol. 1(3): 71-75.

Blagojev N, Skrinjar M, Veskovi -Ora anin S, Šošo V. 2012. Control of mould growth and mycotoxin production by lactic acid bacteria metabolites. Romanian Biotechnol Lett. 17(3): 7219-7226.https://doi.org/10.1016/j. foodcont.2009.07.011

Chitarra GS, Breeuwer P, Nout MJR, Van Aelst AC, Rombouts FMT. 2003. An antifungal compound produced by Bacillus subtilis YM10-20 inhibits germination of Penicillium roqueforti conidiospores. J Appl Microbiol. 94: 159. DOI: $10.1046 / j .1365-2672.2003 .01819 . x$

Cotty PJ. 1988. Aflatoxin and sclerotial production by Aspergillus flavus: Influence of $\mathrm{pH}$. Phytopathol. 78: 1250-1253.DOI: 10.1094/Phyto-78-1250.

Das MP, Rebecca LJ, Sharmila S, Kumar S. 2013. Bacillus amyloliquefaciens MS-3: An antagonistic bacterium against clinical isolates. Res J Pharm Biol Chem Sci. 4 (2):1744-1748.

FAO (Food and Agriculture Organization). 2004. Worldwide regulations for mycotoxins in food and feed in 2003. FAO Food and Nutrition Paper no. 81. FAO, Rome, Italy, pp. 1728-3264.

Gheorghe A, Jecu L, Voicu A, Popea F, Rosu A, Roseanu A. 2008. Biological control of phytopathogenis microorganisms with antagonistic bacteria. www.aidic. it/IBIC2008/webpapers/64Gheorghe.pdf.

Hai NN. 2006. Bacillus subtilis possibly used for aflatoxin control. In Proc. of International Workshop on Biotechnology in Agriculture, Nong Lam Univ., Ho Chi Minh city, Vietnam, Oct. 20-21, 2006.

IARC.1993. International Agency for Research on Cancer: Monograph on the Evaluation of carcinogenic risk to Human, vol. 56, pp. 257 263.Lyon, France.

Kong Q, Shan S, Liu Q, Wang X,Yu F. 2010. Biocontrol of Aspergillus flavus on peanut kernels by use of a strain of marine Bacillus megaterium. Int J Food Microbiol. 139: 31-35.doi: 10.1016/j.ijfoodmicro.2010.01.036.

Li P, Zhang Q, Zhang D, Guan D, Xiaoxia Liu DX, Fang S, Wang X, Zhang W. 2011. Aflatoxin measurement and analysis. In: Irineo Torres-Pacheco (Ed.). Aflatoxins 
detection, measurement and control. ISBN: 978-953307-711-6, In Tech.

Lim Y, Ryu JS, Shi S, Noh W, Kim E, Le QV, Lee HS, Ro HS. 2008. Isolation of Bacteria associated with the King Oyster Mushroom Pleurotus seryngii. Mycobiology. 36(1): 13-18.doi: 10.4489/MYCO.2008.36.1.013

Luna-Romero I, Carvajal M, Carrillo-Castaneda G, Flores C. 2007. Inhibitory compound of the soil bacteria Pseudomonas fluorescens against the fungus Aspergillus flavus L. Rev Mexicana de Micol. 24(1): 19-31.

Nayak S, Dhua U, Samanta S. 2014. Occurrence of aflatoxigenic Aspergillus flavus in stored rice and rice based products of coastal Odisha, India. Int $J$ Curr Microbiol Appl Sci. 3(6): 170-181.

Makun HA, GbodiT A, Akanyal OH, Ezekiel AS, Ogbadu GH. 2007. Fungi and some mycotoxins contaminating rice (Oryza sativa) in Nigeria State, Nigeria. African $J$ Biotechnol. 6(2): 99-108.

Moshafi MH, Forootanfar H, Ameri A, Shakibaie M, Dehghan-Noudeh G, Razavi M. 2011. Antimicrobial activity of Bacillus sp. strain Fas 1 isolated from soil. Pakistan J Pharma Sci. 24: 269-275.

Moyne AL, Shelby R, Cleveland TE, Tuzun S. 2001. Bacillomycin D: an iturin with antifungal activity against Aspergillus flavus. J Appl Microbiol. 90(4): 622-629. https://doi.org/10.1046/j.1365-2672.2001.01290.x.

Mushtaq S, Ali A, Khokhar I, Mukhtar I. 2010. Antagonisitic potential of soil bacteria against food borne fungi. World Appl Sci J. 11(8): 966-969. DOI: 10.2298/ PIF1801009M.

Palumbo JD, O'keeffe TL, Abbas HK. 2007. Isolation of maize soil and rhizosphere bacteria with antagonistic activity against Aspergillus flavus and Fusarium verticillioides. J Food Prot. 70(7): 1615-1621.https:// doi.org/10.4315/0362-028X-70.7.1615.

Pusey PL,Wilson CL. 1984. Postharvest biological control of stone fruit brown rot by Bacillus subtilis. Plant Dis. 68: 753-756.DOI10.1094/PD-69-753.

Ranjbariyan AR, Shams-Ghahfarokhi M, Kalantari S, Razzaghi-Abyaneh M. 2011. Molecular identification of antagonistic bacteria from Tehran soils and evaluation of their inhibitory activities toward pathogenic fungi. Iranian J Microbial. 3(3): 140.

Rollins JA, Dickman MA. 1998. Increase in endogenous andexogenous cyclic AMP levels inhibits sclerotial development in Sclerotinia sclerotiorum. Appl Environ Microbiol. 64: 2539-2544.

Sharma B, Singh M. 2015. Isolation and characterization of bacteria from cow dung of desi cow breed on different morpho-biochemical parameters in Dehradun, Uttarakhand, India. Int J Adv Pharm Biol Chem. 4(2): 276-281.

Stein T. 2005. Bacillus subtilis antibiotics: structures, syntheses and specific functions. Mol Microbiol.56: 845-857.DOI: 10.1111/j.1365-2958.2005.04587.x.

Swain MR, Ray RC. 2009. Biocontrol and other beneficial activities of Bacillus subtilis isolated from cow dung microflora. Microbiol Res. 164(2): 121-130.https://doi. org/10.1016/j.micres.2006.10.009.

Swain MR, Ray RC, Nautiyal CS. 2008. Biocontrol efficacy of Bacillus subtilis strains isolated from cow dung against postharvest yam (Dioscorea rotundata L.) pathogens. Curr Microbiol. 57(5): 407-411.https://doi. org/10.1007/s00284-008-9213-x.

Teo KC, Teoh SM. 2013. Preliminary biological screening of microbes isolated from cow dung in Kampar. African $J$ Biotechnol. 10(9): 1640-1645.

Thakaew R, Niamsup H. 2013. Inhibitory activity of Bacillus subtilis BCC 6327 metabolites against growth of aflatoxigenic fungi isolated from bird chili powder. Int J Biosc Biochem Bioinfo. 3:27-32.DOI: 10.7763/ IJBBB.2013.V3.157.

Wicklow DT, Shotwell L. 1983.Intrafungal distribution of aflatoxinsamong conidia and sclerotia of Aspergillus flavus and Aspergillus parasiticus. Can J Microbiol. 29: 1-5.DOI: 10.1139/m83-001.

ZhangT, Shi ZQ, Hu LB, Cheng, LG, Wang F. 2008. Antifungal compounds from Bacillus subtilis B-FS06 inhibiting the growth of Aspergillus flavus. World $J$ Microbiol Biotechnol. 24(6): 783-788.DOI: 10.1007/ s11274-007-9533-1. 